\author{
REVIEW OF COMPARATIVE LAW \\ VOLUME XXVI-XXVII \\ YEAR 2016
}

\title{
LEGAL AND THEORETICAL ASPECTS OF PROPERTY TAXES
}

\author{
Agnieszka Żywicka*, Tomasz Wotowiec**
}

ABSTRACT:

A property tax (or millage tax) is a levy on property that the owner is required to pay. The tax is levied by the governing authority of the jurisdiction in which the property is located; it may be paid to a national government, a federated state, a county or geographical region, or a municipality. Multiple jurisdictions may tax the same property. This is in contrast to a rent and mortgage tax, which is based on a percentage of the rent or mortgage value. There are four broad types of property: land, improvements to land (immovable man-made objects, such as buildings), personal property (movable man-made objects), and intangible property. Real property (also called real estate or realty) means the combination of land and improvements. Under a property tax system, the government requires and/or performs an appraisal of the monetary value of each property, and tax is assessed in proportion to that value. Forms of property tax used vary among countries and jurisdictions. Real property is often taxed based on its classification. Classification is the grouping of properties based on similar use. Properties in different classes are taxed at different rates. Examples of different classes of property are residential, commercial, industrial and vacant real property. A special assessment tax is sometimes confused with property tax. These are two distinct forms of taxation: one (ad valorem tax) relies upon the fair market value of the property being taxed for justification, and the other (special assessment) relies upon a special enhancement called a "benefit" for its justification.

Keyword: property tax, real property, ad valorem taxation, land, mortgage value

* Dr, Wyższa Szkoła Ekonomii i Innowacji w Lublinie.

${ }^{* *}$ Dr hab., prof. nadzw., Wyższa Szkoła Ekonomii i Innowacji w Lublinie. 


\section{INTRODUCTION}

A tax means a compulsory financial obligation imposed on a taxpayer (an individual or a legal entity) by the state or functional equivalent. Currently it is most often collected in monetary form, though in pre-capitalism times it was often performed in kind. Regardless of the social and political formation of the state organism, it was first the ruler (prince, king, emperor, etc.), and then the state that needed and still needs the means (money or other goods) to satisfy its needs and to perform its tasks (obligations) towards its subordinates or citizens. These means initially came from the property of the ruler, from compulsory contributions collected from the population of defeated areas and from voluntary contributions of the population for its ruler. These contributions, due to their long-term nature, became a habit and as a result, transformed into something valid. These customary and obligatory performances, at a certain stage of socio-economic development gave rise to what we know as contemporary tax ${ }^{1}$.

The initial forms of taxation were based on estimated values of various property elements. Thus they were direct forms of property taxation. Taxation of property was based on the area of the land cultivated by a farmer, regardless of whether it was his property or lease. Later, other parameters of taxation base were taken into account: the state of the field, fertility of the soil (quality), dryness, humidity of the soil or its location. Another form of taxation was tax imposed on livestock. Taxation based on the size of arable land is a substitute for distribution of crops, related to tax on real estate or property, while tax on livestock referred to moveable property. This allowed to tax also craftsmen and merchants on resources they possess $^{2}$.

1 See Stanisław Dolata. Podstawy wiedzy o podatkach i polskim systemie podatkowym, Uniwersytet Opolski, Opole 1999.

2 Ferd H.M. Grapperhaus. Podatki przez wieki. Historia wizualna, TNOiK, Toruń 2010, pp. 22-23. 


\section{PROPERTY AS A SUBJECT OF TAXATION}

The notion of property constitutes one of the most ambiguous categories, differently defined and interpreted depending on a given field of science. Analyzing legal provisions of the EU countries which regulate the issues of tax accounting and tax law, we may determine the general properties of elements of property. These are:

- Ability to generate future economic benefits;

- Reference to transactions or other events realized in the past;

- Remaining under control of the managing unit, which allows to enter them into the accounting system of a given entity.

Taking into account legal provisions of accounting, there are two categories of property (asset) elements: fixed assets and current assets. We can also classify property (assets) using other criteria (graph 1).

Table 1 Types of property (assets) elements according to accounting regulations

\begin{tabular}{|l|c|}
\hline \multirow{2}{*}{ Period of use criterion } & fixed assets \\
\hline Liquidity criterion & current assets \\
\hline Criteria of nature and function & non-liquid \\
& liquid \\
& tangible \\
& intangible \\
& financial \\
\hline
\end{tabular}

Source: own work

The difference between current assets and fixed assets is important for the possible establishment of the tax collection point for the taxes whose taxation base is related to the subject resource. It seems that potential application of property-related tribute requires for the object of taxation 
to be easily identifiable, thus demonstrating certain regularity of its taxation. The review of the existing models of property tax shows that as far as tributes imposing burden on real estate are concerned, there is the primacy of building or land real estate over other types of property. It seems essential that the material property and intangible and legal values, as essential production factors of an enterprise, should constitute the main elements of the fixed assets structure. To describe the real estate, the basic element of property, we should not only use the presentation of various ways of defining the notion of real estate by the lawmakers, but also take into account their features (Table 2).

Table 2 Features of real estate

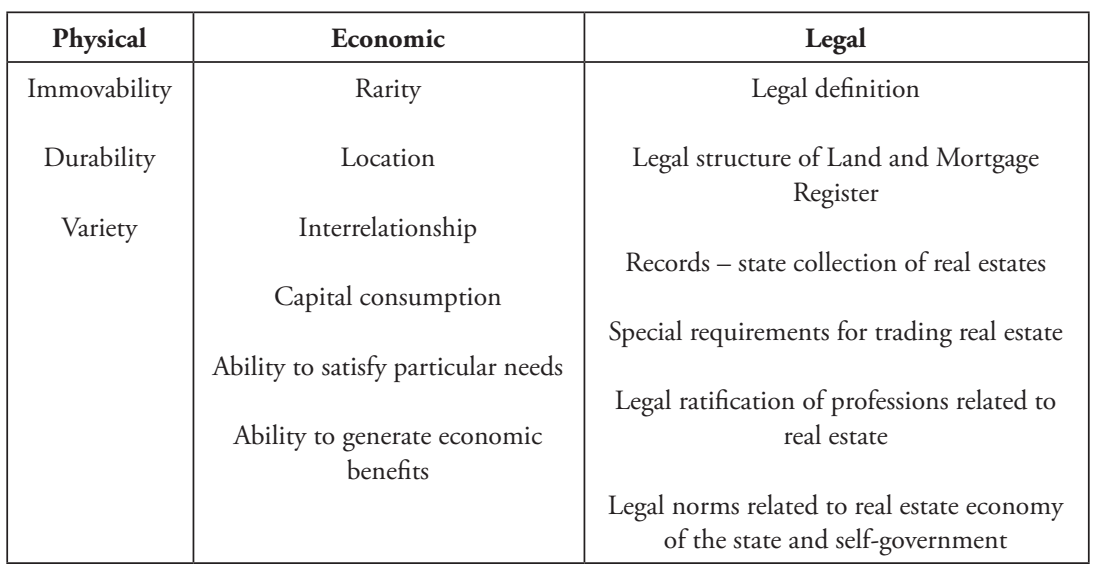

Source: own work.

Analyzing legal aspects concerning real estate in the EU countries we may differentiate four elements which need to be taken into account when considering the forms and structures of property taxation. First of all, it is the immovability of real estate in time and space. The value of the real estate largely depends on the attractiveness of its location and the type of its use. Secondly, variety, manifested in the fact that there no two identical real estates. The factors that differentiate real estate are especially its area, shape, type of development, allocation in the spatial development plan, 
soil conditions, water conditions, utilities, neighborhood. That explains why there might be considerable differences between similar, but hardly comparable real estates. Thirdly - capital and time consumption with reference to industrial developed real estate. Limited financial resources allocated for purchasing the real estate depend on the investor's own resources and availability of external (foreign) finance. The indicated difficulties related to such investment are compensated by the long-term nature of the real estate enjoyed by the owner. A general rule states also that large capital consumption of the real estate usually results in its increasing value. Fourthly, the ability to satisfy particular needs, which means that entrepreneurs are able to generate economic benefits. Each type of real estate has certain functions attached to it. In case of residential real estate - this may be economic, education, cultural, religious activity that can be run there. With reference to undeveloped real estate - conducting trading activities (the marketplace), services (parking lots), agricultural activity (arable land) and forest activity (forest land). Another consequence of possessing a real estate and the right to use it is the ability to generate measurable benefits. The type of benefit depends on the way of using the real estate.

The concept of property has never been defined in the Polish law system. In its wide sense, it is understood as total assets and liabilities belonging to a particular entity. Such definition of property is opposed to its narrow term denoting the estate which entails only assets. In the latter definition, debts do not belong to property, but lower its economic value. Also in economics the property is understood exclusively as a sum of assets - property resources controlled by an individual and possessing reliably defined value. These assets are divided into fixed assets, composed of elements that are permanently engaged in a given unit, and current assets, composed of elements which constantly traded. In this understanding of property, liabilities are treated as means of its origin, and when we juxtapose them with assets, we will obtain a balance sheet ${ }^{3}$. In the legal sense, in the doctrine of civil law property has rather narrow meaning.

Property taxes (on specified items of property), comprise all taxes related to the ownership rights. From the perspective of the relationship

3 Leonard Etel, Grzegorz Liszewski. Podatki majątkowe w Polsce-wybrane problemy, Kancelaria Sejmu, Biuro Studiów i Ekspertyz, Report No 202, Warszawa 2002, p. 5. 
between the tax burden and the taxpayer carrying it, we may differentiate direct and indirect taxes. A direct tax is when there is a precisely defined relationship between tax burden (type of tax, its amount, payment mode) and the taxpayer bearing it directly. Thus we have a relationship between the payment of the tax and direct carrying its burden by the taxpayer. So we have a convergence between the formal and material burden. Direct taxes burden the taxpayer in a way that is closely related to their income or property situation. Direct taxes comprise income taxes and property taxes. Direct taxes, especially property taxes are considered to be non-transferra$\mathrm{ble}^{4}$, which is not the case, therefore the criteria of the unity of a taxpayer and tax burden is not coherent ${ }^{5}$. We should assume therefore - taking into account the criterion of a relationship of the subject with attributable features - that direct taxes are those which are precisely related to permanent and non-transferrable features of a taxpayer or measures of economic activity ascribed to him through the ownership rights (income and property) ${ }^{6}$.

Property taxation has both economic and legal aspects. In the economic aspect, a property tax is the one whose source is the taxpayer's property. If property taxes are paid from obtained income, then they are nominal. If the source from which the tax is paid is the property, that we have real property taxes. Property taxes may burden both the property of individuals and business entities (subject of taxation criterion). We may also single out property taxes which may burden: possession of property, purchase or sale of property and increased value of property. Moreover, the taxation may cover the whole property or its particular elements. A property tax in its normative aspect is a tax which, through the elements of a legal construction (subject and base of taxation) is tied to property ${ }^{7}$.

4 More on transferability and advantages and disadvantages of direct taxes in: Grzegorz Szczodrowski. Polski system podatkowy, PWN, Warszawa 2007, pp. 24-26.

5 Feliks Grądalski. Wstęp do teorii opodatkowania, SGH, Warszawa 2004, p., 105.

${ }^{6}$ More in: Anthony B. Atkinson. Optimal Taxation and the Direct versus Indirect Tax Controversy, "Canadian Journal of Economics", 1977, vol. 6., pp. 590-606.

7 Andrzej Gomułowicz, Jerzy Małecki. Podatki i prawo podatkowe, LexisNexis, Warszawa 2004, pp. 140-141. 


\section{REASONS FOR PROPERTY TAXATION}

Property taxes constitute quite a varied group and are classified in many different ways, just as the property itself is subject to numerous classifications. We may assume that property taxes (on specified items of property) place burden on possessing the property and on its growth. The advantages of property taxes are:

1) they are resistant to tax frauds, as it is difficult to hide the taxation base (estate, real estate or a farm, as well as the fact of, for example, approving the local spatial development plan);

2) since they do not take into account the individual situation of a taxpayer - they do not allow any reliefs aimed at lowering tax burden if due to some special situation, the taxpayer's tax capacity decreases;

3) a relatively simple structure of property taxes (on specific items of property) by eliminating the individual income capacity (lack of personalization) generates low costs of collection;

4) when determining its value, it is easier to resist political pressure, since property tax (on specified items of property) is not related to the taxpayer, so it does not arouse such interest of politicians;

5) property tax allows to cover with taxation those external features of wealth which cannot be taxed with income tax, as they do not bring income, or are not an object of interest for tax organs (collections, yachts, etc.);

6) property tax, by taxation of gathered property does not hinder unlike income taxes - investment (economic) activity.

Disadvantages:

1) the scope of property tax (on specified items of property) is significantly limited, it concerns only to observable objects of taxation;

2) by taxing the possession of property and its growth, we run the risk of excessive taxation of property elements (the rate that destroys property substance) regardless of the income flows generated by the property or an individual income (family) situation of a taxpayer; 
3) the definition of property is not legally precise, but we may differentiate immovable property (forests, land, houses, etc), which is easy to inventory and tax, and movable property (receivables, securities, works of art, intellectual property rights, etc.), with reference to which it is very difficult and costly and sometimes impossible to determine the taxation base and proper tax as it is easy to dodge taxation and hide the taxation base.

Taking into account the specificity of property taxes and advantages and disadvantages of these forms of taxation, it is difficult to identify common features of property tax structures in OECD countries ${ }^{8}$ :

1) in market economy various tax instruments are activated to affect decisions of individuals and entities concerning the use of the property they possess. This means that various tax forms and structures are used, including those reaching incomes obtained from capital, securities, shares, bonds, etc.;

2) practically there are various variants of taxing incomes from property possible - by means of separate property tax (on specific items of property) or within income (revenue) tax;

3) taxation may be imposed on the whole property or only on income obtained from it (taxation of the income flow or the state of possession itself);

4) tax on property of public enterprises is a special form of property tax, as property taxation here constitutes a specific payment: a dividend or participation in profits related to using it;

5) taxation of estate and donations requires separate models and taxation structures due to their specificity compared with other forms of property.

Justifying property taxation we may refer to the principle of equivalence, the principle of payment capacity and principles and political and social rules of population income redistribution. The principle of equivalence is based on an assumption that there is a relationship between the amount of tax burden and the value of public goods and services provided

8 Natalia Gajl. Modele podatkowe. Podatki majątkowe, Wydawnictwo Sejmowe, Warszawa 1996, pp. 43-44; also: Europejskie systemy opodatkowania nieruchomości, edited by Leonard Etel, Biuro Studiów i Ekspertyz, Kancelaria Sejmu, Warszawa 2003, pp. 7-24. 
for the taxpayer. Property tax is a good example of applying this principle. The state takes on the responsibility of protecting ownership rights, incurs expenses related to developing and maintaining economic infrastructure, tries to preserve social peace favoring full and free use of one's ownership. Local authorities take care of the roads, water and sewage systems, green areas, provide light in streets and keep the town tidy. Such activities not only allow to fully use the possessed property but also increase its market value. Due to the fact that most of the above-listed expenses are incurred by local authorities, property taxes mostly credit local budgets?

On the other hand, the relationship between the amount of property taxes and payment capacity is mostly affected by the measures of wealth and related capacity to carry tax burden accepted by the society. Such a criterion can be the current income of a taxpayer, the level of their consumption expenses or gathered property, as thanks to the possessed property they may obtain higher current income. In contemporary tax structures it is usually income that is used as a measure of payment capacity. Both the structure and the amount of property tax rates depend on whether these taxes are treated as independent taxes, or as supplements to other taxes. Property taxes are usually treated as a supplement or correction of income tax in order to better reflect the taxpayer's payment capacity or to allow redistribution of incomes determined by social reasons.

\section{THE LEGAL TAXONOMY OF PROPERTY}

"Immovable property" generally encompasses both "real property" and "real estate," terms that have different technical meaning but that often are used synonymously. Real property refers to the rights, interests and benefits connected with real estate, which is the physical piece of land and any structures on that land. Land, in turn, can have the same meaning as real estate. Much of the literature on national property tax systems speaks generally of "property taxes." Particularly when considering prop-

9 Anna Krajewska. Podatki. Unia Europejska, Polska, Kraje Nadbattyckie, PWE, Warszawa 2004, p. 112-113. 
erty tax revenues, it can be important to distinguish among the various kinds of taxes on property. The International Monetary Fund (IMF) and the Organisation for Economic Co-operation and Development (OECD) have developed largely complementary schemes for classifying taxes, which they use in presenting revenue statistics. Taxes on property include: (1) recurrent (annual) taxes on real (immovable) property, (2) recurrent taxes on net wealth, (3) taxes on estates, inheritances, and gifts, (4) taxes on financial and capital transactions (including real property transfers), (5) other non-recurrent taxes, and (6) other recurrent taxes on property (including taxes on movable property such as vehicles and machinery and equipment). Many countries do not have a uniform national property tax system. Several have separate land and building taxes. Several essentially let local governments tailor their systems to local conditions ${ }^{10}$.

Immovable property taxes are suited to local governments because it is clear which government is entitled to the tax revenue from immovable property, and such property cannot flee the tax collector. Local government services are often provided to properties or their owners and occupants. The tax captures for local government some of the increases in the value of land that are partially created by public expenditures. A dedicated source of revenue promotes local autonomy. The visibility of property taxes focuses attention on the overall quality of governance and promotes accountability. Information on land, buildings, and market prices collected in the course of administering taxes on immovable property becomes part of a valuable pool of information that has numerous governmental and private uses. If up-to-date and publicly available, this information can facilitate orderly real property markets. Despite their advantages - or perhaps because of some of them - property taxes often are underutilized sources of revenue. A common, but disputed complaint about the property tax is that it is inherently regressive, although poorly administered property taxes tend to be regressive. People schooled in income and consumption tax administration can fail to appreciate the relative advantages of a wealth tax. They focus on high administrative costs and low yields, overlooking the comparative high compliance costs associated with income and con-

10 Property Tax Regimes in Europe, The Global Urban Economic Dialogue Series, United Nations Human Settlements Programme, Nairobi 2013, p. 1. 
sumption taxes. Valuers schooled in traditional single-property valuation methods disdain assessors and the mass valuation methods used in property taxation. The unpopularity of property taxes, coupled with opposition from taxpayers who benefit from entrenched inequities encourages "legislative neglect." 11

The greatest discrepancies and irregularities between the science and practice of economics concerns the legal interpretation of the property tax term. It is generally accepted that these performances are directly (or less indirectly) related to the possessed property - so they may burden the fact of possessing it and the fact of increasing it with exceptional circumstances. Sometimes revenue taxes also constitute a burden on a single (exceptional) property growth. However, to be able to differentiate them from property taxes, we need to supplement the definition of the latter with a statement that their structural tie with property is manifested - with only the object of taxation - in the structure of the taxation base: as we can easily prove, when defining the taxation base of income taxes, what comes to the foreground is the value of the actual benefit gained by the taxpayer - it does not necessarily have to coincide with the market value of the objects which account for property gain, and only in a few situations tax authorities can question the value declared by the taxpayer, adopting market-related values. The opposite is true in property taxes: as a rule the taxation base is the market value of an object being property gain, the so-called pure value after deducting some costs and debts related to that object - and this is the value the taxpayer can declare, even if the subjectively indicated object has a much higher value for them than market value.

Property taxes may be classified in many different ways. One of the criteria may be the frequency of imposing them. In this case we may talk of single (one-off) tributes (extraordinary), usually imposed in times of temporary deficit in the state budget, valid for a limited period of time, and of regular tribute - imposed for a specific time. Property taxes may also be divided into direct and indirect, with several criteria of such division. We may also apply the criteria of collection technique to property

11 Enid Slack. The Property Tax - in theory and Practice. Institute on Municipal Finance and Governance, Munk School of Global Affairs, University of Toronto, "IMFG Municipal Finance and Governance" No 2/2011, p. 2-3. 
tribute. Direct taxes in this approach will be those paid by the entities who have direct tax obligation towards territorial self-government unit or Treasury. The economic criterion, referring to the sources of tax coverage, allows us to differentiate nominal and real property tributes. The former are characterized by the fact that it is not necessary to use any part of the property substance to pay them - a given taxpayer may pay his tax obligation with the money coming from current income or savings. On the other hand, property taxes become real when the amount of the required tribute exceeds payment capacities of the obliged entity - in order to pay their whole tax obligation, the taxpayer is forced to cash some of their property, for example - by selling off part of the land. Analyzing property tributes in their legal sense, it must be stated that these are performances related to property through the elements of tax structure, that is taxation base and object. The performances understood in this way may further be divided along another criterion: the way of presenting the object of taxation. It allows us to single out taxes which are imposed on possession of property, sale of property, purchase of property, growth in property value. Property taxes may also be classified according to their function which they play in the tax system.

Property taxes have various legal classifications. Analyzing legislature of the EU and OECD countries, we may differentiate four classification groups of property taxes:

1) Taxes on possessing property (managing property). Depending on the valid tax system these may be taxes on the total value of property belonging to a given economic entity (moveable and immoveable property, cash, bank deposits, etc.), or - more frequently - on its selected elements. In the Polish tax system, the taxes belonging to this group are: tax on real estate, land tax, forest tax and tax on means of transport.

2) Taxes on the increment (taking over) of property. The taxation object here is the obtaining of an object or property rights by means of purchase, donation or inheritance. Here we classify tax on inheritance and donations.

3) Taxes on the growth of value of the possessed property. They are used when this growth can be attributed to reasons not associated with the owner. An example here can be a betterment levy 
(fee) and re-zoning fee, paid by real estate owners due to the fact that their properties gained in value as a result of providing services and utilities, geodetic division of land, changes to local spatial development plan, etc.

4) Taxes on transformation of property substance. These are taxes paid in case of the sale or exchange of things or property rights into other things or property rights. In Poland, they are present as tax on civil law activity (Polish abbreviation - PCC).

In principle, a tax on land value only taxes location rents (returns on a particular location regardless of how distributed, such a tax should be more progressive than a tax on land and improvements. Site value taxation thus scores well in terms of both equity and efficiency. Indeed, taxes on land are generally regarded as one of the least distortionary taxes, although more general taxes on property do, of course, distort decisions about improvements (investment) to property. The valuation of land alone is difficult, however, because most urban real estate sales combine the value of land and improvements. The value of improvements thus needs to be subtracted to derive an assessed value for the land. While some consider such taxation unacceptably arbitrary, others argue that valuation of land alone is probably easier than valuation of property and can often be estimated directly from sales and demolition records ${ }^{12}$. In many such countries, land and improvements are in practice assessed separately in any case, with land value being estimated on the basis of a land value map and building value in accordance with construction cost tables. Another problem with taxing land only, however, is that, since the tax base is considerably smaller than the value of land and improvements combined, a higher and more distortionary rate is needed to generate comparable revenues ${ }^{13}$.

The legal analysis of the structure and features of property taxes allows us to put forward the following classification criteria:

12 See more: Roy Bahl. Land Taxes versus Property Taxes in Developing and Transition Countries. In: Land Value Taxation: Can It and Will It Work Today? ed. Dick Netzer. Lincoln Institute of Land Policy, Cambridge, MA.

13 Richard M. Bird, Enid Slack. Land and property taxation in 25 countries: a comparative review. "CESifo DICE Reaserch Report" No 3/2005, pp. 34-35. 
1. he legal and economic process of generating and using income (the object criterion).

2. Specification of the object of taxation (economic criterion).

3. The relationship between normatively determined elements of the taxation technique (source, object, subject of tax) and the actual state (criteria of allocation of financial resources coming from taxes).

4. The method of quantifying the taxation base.

Analyzing the assumed reasons for choosing a particular form of taxation, we may assume that the first two criteria are similar. In both the basic problem consists in selecting the object of taxation. In the object criterion, taxes may be imposed on income, property or turnover and expenses. In case of economic and legal criteria, clear specification of the taxation object becomes important. We distinguish income taxes (the object of taxation is property as it is generated), capital taxes (here the taxation object is the existing property) and taxes on turnover and expenses (the expended property is the object of taxation here $)^{14}$. The makers of tax laws have definite possibilities related to the choice of the tax collection points, namely:

1) Taxation of the current activity of taxpayers in form of flows related to: collection of taxes in a situation of generating and then consuming income and collecting taxes in a situation of accumulating capital (saving or investing);

2) Taxation of the resource, that is the property accumulated in the past.

The choice of the structure of the tax system should depend on many factors related to the performance of the basic functions of taxes. Here we can use the following criteria:

- Fiscal efficiency of taxes, collection costs, resistance to tax avoidance and frauds, speed and ease of obtaining income from taxes, ability to self-regulate;

- Influence of taxes on inclination to save and invest, influence on the choice of socially desirable production techniques, materials,

14 Felis Paweł. Elementy teorii i praktyki podatków majątkowych. Poszukiwanie tadu $w$ opodatkowaniu nieruchomości $w$ Polsce z perspektywy przedsiębiorców oraz jednostek samorządu terytorialnego. Szkoła Główna Handlowa w Warszawie, Warszawa 2012, pp. 72-73. 
sources of energy, influence on the choice of socially desirable structure of consumption - in case of the motivating function of taxation.

Table 3 Types of property taxes according to events considered to be the object of taxation on the example of Poland

\begin{tabular}{|l|l|}
\hline \multicolumn{1}{|c|}{ Event - object of taxation } & \multicolumn{1}{c|}{ Type of property tax } \\
\hline Possessing property & $\begin{array}{l}\text { Tax on real estate } \\
\text { Tax on arable land } \\
\text { Forest tax } \\
\text { Tax on transport means }\end{array}$ \\
\hline Using production means in a production process & $\begin{array}{l}\text { Tax on arable land } \\
\text { Forest tax } \\
\text { Tax on transport means }\end{array}$ \\
\hline Taking over property & Tax on inheritance and donations \\
\hline Transactions of sale and purchase of property & Tax on civil law activities \\
\hline
\end{tabular}

Source: own work.

We should remember that there is no unanimous agreement among taxation theoreticians as to clear classification of particular taxes into groups of property taxes. This especially concerns arable land and forest tax, which may be classified as revenue taxes, as they refer to external features indicating the size of income obtained by the taxpayer (in case of the arable land tax, they refer to the amount, quality and type of land). Analyzing the functions and the construction of the arable land and forest tax, we may also claim that these two taxes are not typical revenue taxes, but revenue-property taxes. An essential problem in the classification of the arable land and forest tax is the fact that the law-makers excluded revenues from agricultural and forest activity from the regulations governing income taxes, as understood by the provisions of the acts on agriculture $\operatorname{tax}^{15}$ and

15 The Act of 15th November 1984 on Agriculture Tax (Journal of Laws 1984 No 52 item 268, as amended). 
forest $\operatorname{tax}^{16}$. Performing a complex analysis of the forest and agriculture tax structure, we may state that the agriculture and forest taxes constitute a burden on property, as the tax obligation is created solely by the fact of possessing or owning arable land, even if there is no agricultural or forest activity conducted on this land. Also with reference to the tax on real estate, regulated in the Polish act on local taxes and fees ${ }^{17}$, we may notice a certain legal relationship with the category of property-revenue taxes ${ }^{18}$. Analyzing the structure of real estate tax we may notice that the level of tax burden depends on the way in which the real estate is used. This concept is in line with a principle stating that using real estate in economic activity may allow us to gain greater property benefits, therefore it is justifiable to tax it higher than in case of possessing other real estate objects, such as a residential house.

\section{RECURRENT TAXES ON IMMOVABLE PROPERTY}

Traditional land and property taxation - commonly referred to as property taxation - is based on the "combined assessed value of land, buildings and improvements thereon" 19 . This is the most widely used form of taxation and this is what they mean when a typical mayor and public finance official talk about land and property tax. However, this is not the only form of taxation associated with land. For example, various jurisdictions have over the years attempted to restrict taxes to ownership of land and put forward various justifications for doing so. When taxation is restricted to land or higher tax rates are imposed on land rather than buildings or

16 The Act of $30^{\text {th }}$ October 2002 on Forest Tax (Journal of Laws 2002 No 200 item 1682 , as amended).

17 The Act of $12^{\text {th }}$ January 1991 on Local Taxes and Fees (Journal of Laws 1991, No 9 item 31, as amended).

18 Ryszard Mastalski, Prawo podatkowe, C.H. Beck, Warszawa 2000, p. 492.

19 See more: Owen Connelan, Land Value Taxation in Britain: Experience and Opportunities, LILP, Cambridge 2004, Massachusetts. 
improvements, then taxation takes the form of land value taxation (also called site value rating ${ }^{20}$.

Land value taxation (LVT), also known as recurrent property taxation, is often considered fair and progressive. As such, LVT claims to enhance efficiency of the use of land-based taxation in general and may discourage land and real estate speculation. The land value taxation in its pure form intends to let the landowners bear the full cost of the taxation with limited possibility to shift the cost to users (renters). In principle, land value approach does not enforce density and the timing for developing a parcel of land. Land value taxation advocates often argue for a single local land tax, at the expense of other factors of production (e.g. capital and labor). In so doing, land value taxation supports the abolition or reduction of taxation revenues (fees, rates, charges) from income, development, sales, various municipal services, building values, corporate profit etc. Further, LVT tends to decrease the dependency of local government on 'central' government revenue.

Despite these arguments, land value capture and taxation has limited uptake and traction due to various challenges including legal and administrative issues (reforms needed to abolish other prevailing taxation systems and finding the appropriate institutional arrangements from local to central government role in land-based taxation), assessment methods (how to design and implement a fair valuation method and rolls - by area / site, income, value increment, etc.- and its increments). Another variant of LVT argues for a modified land value taxation that supports a split-rate taxation system whereby the tax receipts separate the value or tax rate of land from the improvements on land. However, pure single land tax does not exist and "in those jurisdictions where land value taxation has been tried, it has typically taken the form of a two-rate tax, not a pure land value tax." ${ }^{21}$ In practice, many countries have adopted some forms of LVT along with property and other taxation and revenue sources (income, sale, increment,

20 Remy Sietchiping ed. Innovative Land and Property Taxation, United Nations Human Settlements Programme (UN-HABITAT), Nairobi, p. 4.

21 See more: Richard F. Dye, Richard W. England Assessing the theory and practice of land value taxation, Policy Focus Report of for the Lincoln Institute of Land Policy, 2010, p.12. 
improvement, etc.). Property taxation is broadly concerned with raising revenue on structures and improvements over land. Taxing improvements (e.g. using betterment levies) often raises ethical questions, particularly its fairness and regressiveness. Unlike land value taxation, land and property based taxation are often a mixture of revenue streams and collection methods from local to national levels. Property taxation often considers both land and improvements. In fact, many countries apply a one-rate property tax system that takes into account both the land component land the improvements value. Taxation may have an indirect, but significant effect on urban spatial planning in that it impacts on the amount of land released for urban development thus contributing to transactions of land parcels. For example, to achieve city density and mix, manage urban sprawl, overall distances of daily commutes and control of urban sprawl. Two main types of land and property taxation (including taxing the improvements on land) regimes are predominant in urban areas: annual land rent and an annual building tax. Land rent is paid by both permit holders and leaseholders and is in addition to the payments due under the lease agreements. Land rents paid to government for land held under leases should reflect a valuation based on location and accessibility.

All surveyed European countries have at least one tax on property, and most have several. Of the forty-six countries surveyed, at least forty-four have at least one recurrent tax on immovable property (Malta and San Marino do not). Table 1 attempts to provide a snapshot of the current situation. It summarizes which countries use which types of taxes and which tiers of government receive revenues from taxes on property. Based on data from IMF 2010, columns 2 through 7 in Table 4 characterize reliance on a particular kind of tax as "no," "low," "mid," or "high." For reliance to be characterized as "low" (cells highlighted in green), the revenues from that tax as a percentage of all tax revenues in the country did not exceed the 25th percentile of the countries reported as levying such a tax in IMF 2010 (the percentages associated with the percentiles can be found at the bottom of the table). Similarly, those characterized as "high" (cells highlighted in pink) fell above the 75th percentile. Those characterized as "mid" (cells highlighted in yellow) fell between "low" and "high." IMF data were not available or were in question for several countries (those with "n.a." for 
"not available" or those with cells highlighted in gray). As indicated in the notes to the table, some adjustments to the data were made.

As illustrated in Table 2 (following Table 4), some countries have more than one recurrent tax on immovable property. The table identifies taxes assessed against land alone - that is, buildings are not subject to the tax (column 2), taxes assessed against buildings (and other structures) alone (column 3), and taxes assessed against both land and buildings (column 4). Under the latter type of tax, land and buildings can be assessed separately or land and associated buildings can be assessed as a single economic unit. However, a single law as opposed to separate laws, lays out how land and buildings are to be taxed. Column 5 indicates whether movable property is taxed. The most commonly taxed categories of movables are business machinery and equipment and certain vehicles, aircraft and watercraft. Table 5 also indicates the basis for the tax. Capital value-based taxes are indicated by "CV;" annual rental value-based taxes, by "AV;" and areabased taxes, by "Area." As discussed in the section, "Basis of Assessment," the values in value-based taxes can have different conceptual bases and origins. Thus, the values can closely track current market prices, or they can be completely divorced from current market prices.

Table 4 Property taxes imposed and distribution of property tax revenues

\begin{tabular}{|c|c|c|c|c|c|c|c|c|c|}
\hline \multirow{2}{*}{$\begin{array}{c}\text { Country } \\
\text { (EU member } \\
\text { States) }\end{array}$} & \multicolumn{6}{|c|}{ Property taxes utilized \& relative reliance on each type of tax } & \multicolumn{3}{|c|}{$\begin{array}{l}\text { Revenue recipients (\% of } \\
\text { total property taxes }\end{array}$} \\
\hline & $\begin{array}{l}\text { Recurrent, } \\
\text { immovable }\end{array}$ & \begin{tabular}{|c} 
Re- \\
current, \\
net \\
wealth
\end{tabular} & $\begin{array}{c}\text { Estates, } \\
\text { inheritance } \\
\text { gifts }\end{array}$ & $\begin{array}{c}\text { Financial } \\
\& \\
\text { Capital } \\
\text { transfer }\end{array}$ & $\begin{array}{l}\text { Other } \\
\text { nonre- } \\
\text { current }\end{array}$ & $\begin{array}{c}\text { Other } \\
\text { re- } \\
\text { current } \\
\text { pro- } \\
\text { perty }\end{array}$ & central & $\begin{array}{c}\begin{array}{c}\text { State } \\
\text { (regio- } \\
\text { nal) }\end{array} \\
\end{array}$ & local \\
\hline$(1)$ & (2) & (3) & (4) & $(5)$ & (6) & (7) & $(8)$ & (9) & $(10)$ \\
\hline Austria & Low & No & Mid & Mid & No & No & 1,4 & 4,4 & 81,2 \\
\hline Belgium & High & Mid & High & High & Mid & No & 11,3 & 51,6 & 37,1 \\
\hline Bulgaria & Mid & No & High & No & No & High & 0,0 & 0,0 & 100,0 \\
\hline Croatia & Low & No & Low & Mid & No & No & 51,7 & 0,0 & 48,3 \\
\hline Cyprus & Mid & Mid & Mid & Low & No & No & 91,7 & 0,0 & 8,3 \\
\hline Czech R. & Low & No & Low & Mid & No & No & 67,1 & 0,0 & 32,9 \\
\hline Denmark & Mid & Mid & Mid & Low & No & No & 50,7 & 0,0 & 49,3 \\
\hline Estonia & Mid & No & No & No & No & No & 0,0 & 0,0 & 100,0 \\
\hline
\end{tabular}




\begin{tabular}{|c|c|c|c|c|c|c|c|c|c|}
\hline Finland & Mid & No & \begin{tabular}{|l|} 
High \\
\end{tabular} & Mid & No & No & 55,4 & 0,0 & 44,6 \\
\hline France & High & High & High & Mid & No & Mid & 19,3 & 0,0 & \begin{tabular}{|l|}
80.7 \\
\end{tabular} \\
\hline Germany & Low & Mid & Mid & High & Mid & High & 0,0 & 52,3 & 47,7 \\
\hline Greece & Low & Mid & Mid & High & Mid & High & 87,8 & 0,0 & 12,2 \\
\hline Hungary & Mid & No & Mid & Mid & No & No & 37,6 & 0,0 & 62,4 \\
\hline Ireland & High & No & Mid & No & No & No & 19,4 & 0,0 & 80,6 \\
\hline Italy & Mid & Mid & Mid & No & No & Mid & 4,5 & 0,0 & 95,5 \\
\hline Latvia & Mid & No & No & No & No & No & 0,0 & 0,0 & 100,0 \\
\hline Lithuania & Mid & No & Low & No & No & No & 0,0 & 0,0 & 100,0 \\
\hline Luxembourg & Mid & Low & Low & Mid & No & No & 92,2 & 0,0 & 7,8 \\
\hline Malta & No & No & Mid & High & No & No & 100,0 & 0,0 & 0,0 \\
\hline Netherlands & Mid & Low & \begin{tabular}{|l|} 
High \\
\end{tabular} & High & No & Mid & 69,3 & 0,0 & 30,7 \\
\hline Poland & High & No & Mid & No & No & Low & 0,0 & 0,0 & 100,0 \\
\hline Portugal & Mid & No & Low & Mid & No & No & 0,4 & 0,0 & 99,6 \\
\hline Romania & High & No & No & Low & No & No & 2,8 & 0,0 & 97,2 \\
\hline Slovakia & Mid & No & Low & Low & No & No & 0,6 & 0,0 & 99,4 \\
\hline Slovenia & Mid & Low & Mid & Low & No & No & 0,0 & 0,0 & 100,0 \\
\hline Spain & High & Mid & High & High & Mid & No & 0,7 & 58,9 & 40,4 \\
\hline Sweden & Mid & No & Low & Mid & No & No & 60,8 & 0,0 & 39,2 \\
\hline $\begin{array}{l}\text { United } \\
\text { Kingdom }\end{array}$ & High & No & Mid & Mid & High & No & 68,7 & 0,0 & 31,3 \\
\hline $\begin{array}{l}\text { Reliance } \\
\text { benchmarks }\end{array}$ & \multicolumn{9}{|c|}{ Indicated type of tax as a percentage of total taxes } \\
\hline Low & $\leq 0.0113$ & $\leq 0.0010$ & \multicolumn{2}{|c|}{\begin{tabular}{l|l}
0 & $\leq 0.0008$ \\
\end{tabular}} & $\leq 0.0073$ & \multicolumn{2}{|c|}{$\leq 0.0008$} & \multicolumn{2}{|c|}{$\leq 0.0001$} \\
\hline Mid & \begin{tabular}{|l|}
$0.0114-$ \\
0.032 \\
\end{tabular} & $\begin{array}{l}0.0011- \\
0.0241 \\
\end{array}$ & \multicolumn{2}{|c|}{$0.0009-0.0105$} & \begin{tabular}{|l|}
$0.0074-$ \\
0.0151 \\
\end{tabular} & \multicolumn{2}{|c|}{$0.0009-0.0021$} & \multicolumn{2}{|c|}{\begin{tabular}{|l|}
$0.0002-0.0073$ \\
\end{tabular}} \\
\hline High & $>0.032$ & $>0.0241$ & \multicolumn{2}{|c|}{$1>0.0105$} & $>0.0151$ & \multicolumn{2}{|c|}{$>0.0021$} & \multicolumn{2}{|c|}{$>0.0073$} \\
\hline
\end{tabular}

Source: Property Tax Regimes in Europe, The Global Urban Economic Dialogue Series, United Nations Human Settlements Programme, Nairobi 2013, p. 7-8.

\section{Table 5 Base and Basis of Taxes on Immovable Property}

\begin{tabular}{|c|l|l|l|l|}
\hline County & Land tax & Building Tax & $\begin{array}{l}\text { Real Property (Land \& } \\
\text { Buildings) Tax }\end{array}$ & $\begin{array}{l}\text { Movables } \\
\text { Taxed }\end{array}$ \\
\hline (1) & $(\mathbf{2})$ & \multicolumn{1}{|c|}{$(\mathbf{4})$} & \multicolumn{1}{|c|}{$(5)$} \\
\hline Austria & -- & -- & $\begin{array}{l}\text { Real Property Tax Grundsteurer): } \\
\text { CV }\end{array}$ & -- \\
\hline Belgium & -- & -- & $\begin{array}{l}\text { Onroerende Voorheffing/ } \\
\text { Precompte Immobilier: Annual } \\
\text { rental value (AV) }\end{array}$ & -- \\
\hline
\end{tabular}




\begin{tabular}{|c|c|c|c|c|}
\hline Bulgaria & -- & -- & $\begin{array}{l}\text { Immovable Property Tax (1997; } \\
\text { amended 1998): CV }\end{array}$ & $\begin{array}{l}\text { Certain } \\
\text { vehicles, } \\
\text { aircraft, \& } \\
\text { vessels }\end{array}$ \\
\hline Croatia & \begin{tabular}{|l|} 
Tax on \\
Uncultivated \\
Agricultural \\
Land \\
(2001): Area \\
Unused \\
Construction \\
Land Tax \\
(2001): Area
\end{tabular} & $\begin{array}{l}\text { Tax on Holiday } \\
\text { Houses: } \\
\text { Area }\end{array}$ & $\begin{array}{l}\text { Unused Enterprise Real Estate Tax } \\
\text { (2001): Area }\end{array}$ & -- \\
\hline Cyprus & - & -- & Immovable Property Tax: CV & -- \\
\hline Czech R. & -- & -- & $\begin{array}{l}\text { Real Estate Property Tax (1993): } \\
\text { Area }\end{array}$ & -- \\
\hline Denmark & \begin{tabular}{|l|}
$\begin{array}{l}\text { Land Tax } \\
\text { (Grundskyld, }\end{array}$ \\
1926): CV
\end{tabular} & $\begin{array}{l}\text { Service Tax } \\
\text { (Daekningafgift, } \\
\text { 1961): } \\
\text { CV }\end{array}$ & $\begin{array}{l}\text { Property Value Tax } \\
\text { (Ejendomsvaerdiskat,2000): CV }\end{array}$ & -- \\
\hline Estonia & $\begin{array}{|lr|}\text { Land } & \text { Tax } \\
(1993): & C V\end{array}$ & -- & - & - \\
\hline Finland & - & -- & $\begin{array}{l}\text { Tax on Real Property } \\
\text { (Kiinteistovero; fastighetsskatt, } \\
\text { 1994): CV }\end{array}$ & -- \\
\hline France & $\begin{array}{l}\text { Land Tax } \\
\text { (Taxe } \\
\text { Fonciere (sur } \\
\text { les } \\
\text { proprietes } \\
\text { non } \\
\text { baties)): AV } \\
\end{array}$ & $\begin{array}{l}\text { Housing Tax } \\
\text { (Taxe } \\
\text { d'Habitation): } \\
\text { AV }\end{array}$ & $\begin{array}{l}\text { Land \& Building Tax (Taxe } \\
\text { Fonciere } \\
\text { (sur les proprietes baties)): AV } \\
\text { Local Economic Contribution } \\
\text { (Contribution Economique } \\
\text { Territorale, 2010): AV }\end{array}$ & -- \\
\hline Germany & -- & -- & $\begin{array}{l}\text { Real Property Tax (Grundsteurer, } \\
\text { 1973): CV }\end{array}$ & $\begin{array}{l}\text { Some } \\
\text { livestock } \\
\& \\
\text { agricultural } \\
\text { machinery }\end{array}$ \\
\hline
\end{tabular}




\begin{tabular}{|c|c|c|c|c|}
\hline Greece & -- & $\begin{array}{l}\text { Special Duty on } \\
\text { Buildings } \\
\text { Powered by } \\
\text { Electricity } \\
\text { (2011): Area }\end{array}$ & $\begin{array}{l}\text { State (Large) Real Estate Tax } \\
\text { (2010): CV } \\
\text { Local Real Estate Duty (1997): } \\
\text { CV }\end{array}$ & -- \\
\hline Hungary & $\begin{array}{l}\text { Tax on Plots } \\
(1991)\end{array}$ & $\begin{array}{l}\text { Tax on Buildings } \\
(1991) \\
\text { Tourist Traffic } \\
\text { Tax (on } \\
\text { holiday houses) }\end{array}$ & -- & - \\
\hline Ireland & - & - & $\begin{array}{l}\text { Rates: AV } \\
\text { Non Principal Private Residence } \\
\text { Charge (2009): Flat } € 200 \text { charge } \\
\text { Household Charge (2012): Flat } \\
€ 100 \text { charge }\end{array}$ & - \\
\hline Italy & -- & \begin{tabular}{|l} 
Local \\
Government \\
Business Tax \\
(Imposta \\
comunale \\
sull'industria, \\
arti e professio- \\
ni, 1989) \\
\end{tabular} & $\begin{array}{l}\text { Communal Tax on Immovable } \\
\text { Property (Imposta Comunale } \\
\text { sugli } \\
\text { immobili, 1993): AV }\end{array}$ & -- \\
\hline Latvia & -- & - & Real Property Tax (1998): CV & - \\
\hline Lithuania & $\begin{array}{l}\text { Land Tax } \\
(1990, \\
\text { revised in } \\
1992): C V\end{array}$ & $\begin{array}{l}\text { Real Property } \\
\text { Tax } \\
(2006): C V\end{array}$ & -- & - \\
\hline Luxembourg & -- & - & $\begin{array}{l}\text { Property Tax (Impot foncier, } \\
\text { 1936): } \\
\text { CV } \\
\end{array}$ & - \\
\hline Netherlands & -- & -- & $\begin{array}{l}\text { Immovable Property Tax } \\
\text { (Onroerende-Zaakbelasting or } \\
\text { OZB, 1970): CV }\end{array}$ & $\begin{array}{l}\text { Houseboats } \\
\text { and } \\
\text { the like can } \\
\text { be } \\
\text { taxed. }\end{array}$ \\
\hline Poland & $\begin{array}{l}\text { Agricultural } \\
\text { \& Forest } \\
\text { Land Taxes: } \\
\text { Area }\end{array}$ & -- & Urban Property Tax (1991): Area & -- \\
\hline
\end{tabular}




\begin{tabular}{|c|c|c|c|c|}
\hline Portugal & -- & -- & Municipal Tax (IMI, 1989): CV & -- \\
\hline Romania & $\begin{array}{l}\text { Tax on Land } \\
\text { (1981): } \\
\text { Area } \\
\text { Fee for the } \\
\text { use of } \\
\text { State-owned } \\
\text { land } \\
(1975)\end{array}$ & $\begin{array}{l}\text { Tax on } \\
\text { Buildings } \\
\text { (1981): CV }\end{array}$ & -- & -- \\
\hline Slovakia & - & -- & $\begin{array}{l}\text { Real Estate Tax (1993): Area } \\
\text { (agricultural land: CV) }\end{array}$ & - \\
\hline Slovenia & $\begin{array}{l}\text { Charge for } \\
\text { Use of } \\
\text { Building } \\
\text { Ground } \\
\text { (1995): CV } \\
\end{array}$ & $\begin{array}{l}\text { Property } \quad \text { Tax } \\
\text { (1988): CV }\end{array}$ & -- & Certain ships \\
\hline Spain & - & -- & $\begin{array}{l}\text { Real Estate Tax (Impuesto sobre } \\
\text { Bienes Inmuebles): CV }\end{array}$ & - \\
\hline Sweden & - & -- & $\begin{array}{l}\text { Real Estate Tax (Statlig } \\
\text { Fastighetsskatt, 1985): CV }\end{array}$ & -- \\
\hline $\begin{array}{l}\text { United } \\
\text { Kingdom }\end{array}$ & -- & - & $\begin{array}{l}\text { Uniform Business Rate (England } \\
\text { \& Wales) } \\
\text { Council Tax (England \& Wales) }\end{array}$ & - \\
\hline
\end{tabular}

\section{Notes:}

$\mathrm{CV}$ - means capital value

AV - means annual rental value (often the values are "cadastral" values, specifically used as the basis for the tax).

Area - means the base is land area or some measurement of building area.

Source: Property Tax Regimes in Europe, The Global Urban Economic Dialogue Series, United Nations Human Settlements Programme, Nairobi 2013, p. 9-11.

Although this table focuses on recurrent taxes on immovable property, a few words about recurrent taxes on net wealth and taxes on real estate transfers (a tax on the transfer of wealth) are appropriate. Rudnick and Gordon ${ }^{22}$

22 Rebecca Rudnick, Richard Gordon Taxation of Wealth. In: Tax Law Design and Drafting, ed. Victor Thuronyi. Washington, 1996, International Monetary Fund. http:// www.imf.org/external/pubs/nft/1998/tlaw/ eng/ch10.pdf. 
addressed both kinds, the latter being viewed as taxes on the transfer of wealth. Despite their conceptual appeal, recurrent taxes on net wealth seem to be in decline, although the pictures presented by revenue statistics and by system descriptions can conflict. However, European countries that make substantial use of recurrent taxes on net wealth include France, Luxembourg (on corporations), Norway, and Switzerland. Iceland has temporarily reintroduced a net wealth tax on residents ${ }^{23}$.

Countries that recently abandoned such taxes include such countries like: Denmark, Finland, Luxembourg (on residents), Netherlands, Spain, and Sweden. Taxes on transfers of real property (which are in the IMF category of taxes on financial and capital transactions) are more widely used. Property registration procedures that require price disclosures and value-based transfer taxes - if the rates are moderate - can help in the administration of a value-based recurrent tax on immovable property. High rates can have detrimental effects. Although high real property transfer taxes have a certain political appeal, they create incentives to conceal transfers, actual transfer prices, or both ${ }^{24}$. Such concealments undercut efficient administration of value-based taxes on immovable property, and they can make property markets less efficient and transparent. What constitutes a "high" rate of transfer taxation is subject to debate. In general, however, rates below 2 percent are considered acceptable, and rates of 5 percent or higher are considered detrimental. Countries that appear to exceed this benchmark on some transfers include Belgium, Croatia, Ireland, Luxembourg, Malta, Netherlands, and Spain. Belgium is the only country with a transfer tax rate in excess of 10 percent; its rate is 12.5 percent.

23 See: European Union. (2011) Taxation Trends in the European Union: Data for the EU Member States, Iceland and Norway, <http://ec.europa.eu/taxation_customs/taxation/ gen_info/economic_

analysis/tax_structures/index_en.htm> (accessed 17 December 2011)

24 See more: Roy Bahl, Property Tax Reform in Developing and Transition Countries, Report prepared for the United States Agency for International Development under a contract with Development Alternatives, Inc. under the Fiscal Reform and Economic Governance Task Order, 2009, GEG-I-00-04-00001-00 Task Order No. 07., p. 21. 


\section{CONCLUSIONS}

The design of real estate property tax system is in the last period a subject for debate, attracting attention in the political, social or academic debates. This is due because taxation on real estate property could be ${ }^{25}$ :

a) New source of revenues. In a couple of European countries there is an important need to find new financial resources; the fact that real estate taxes are quite low in many countries creates the opportunity for these countries to obtain a convenient not expensive and short term solution.

b) New source of economic growth. There are recent studies which identified taxes on real estate property as some of the least detrimental to GDP. In this context there are couple of voices which sustain the necessity to move the tax intensity from labor taxes (that discourage employment) towards taxes on consumption and property.

c) A source of stability. Taxes on property are recurrent and offer an important advantage of a high stability of tax revenue flow, which facilitates a reliable budgetary planning. This could be an important issue for indebted economies, an attractive feature particularly for highly indebted countries, for which increasing in stability of revenues is very important in achieving good debt financing conditions on the global capital market.

d) A way to avoid future crisis. There are many voices which consider the favorable tax treatment of mortgages as one of the important contributing factors to the housing price bubble that has played an important role in the crisis in several countries. In this context, it is important to ensure a more balanced tax treatment of housing ${ }^{26}$.

25 See more: Ion Anghel, Richard Grover, Opportunities and constraints on the development of real estate taxation in transitional countries, 14 th Annual European Real Estate Society, www.eres.org, London, June 2007; Jens Arnold, Bert Brys, Christopher Heady, Asa Johansson, Cyrille Schwellnus and Laura Vartia, Tax policy for economic recovery and growth, “The Economic Journal”, No 121/2011,pp. 59-80.

26 See more: Christopher Crowe, Giovanni Dell'Ariccia, Deniz Igan, Pau Rabanal. 2007. How to Deal with Real Estate Booms: Lessons from Country Experiences, IMF "Working Paper", No 4/2011; Richard Grover, Ion Anghel, Virgil Pamfil, Developing quality training approaches for effective property tax administration, ERES-ESSEC Education Seminar, Paris, 


\section{REFERENCES:}

Anghel, Ion, Richard Grover. 2007. Opportunities and constraints on the development of real estate taxation in transitional countries, 14 th Annual European Real Estate Society, www.eres.org, London;

Arnold, Jens, Bert Brys, Christopher Heady, Asa Johansson, Cyrille Schwellnus and Laura Vartia, Tax policy for economic recovery and growth, "The Economic Journal", No 121/2011;

Atkinson, Anthony B., Optimal Taxation and the Direct versus Indirect Tax Controversy, "Canadian Journal of Economics", 1977, vol. 6;

Bahl, Rey, Land Taxes versus Property Taxes in Developing and Transition Countries, [in:] Dick Netzer, ed., Land Value Taxation: Can It and Will It Work Today? Lincoln Institute of Land Policy, Cambridge, MA;

Bahl, Rej. 2009. Property Tax Reform in Developing and Transition Countries, Report prepared for the United States Agency for International Development under a contract with Development Alternatives, Inc. under the Fiscal Reform and Economic Governance Task Order, GEG-I-00-04-00001-00 Task Order No. 07;

Bird, Richard M., Enid Slack, Land and property taxation in 25 countries: a comparative review. "CESifo DICE Reaserch Report" No 3/2005.

Connelan, Owen. 2004. Land Value Taxation in Britain: Experience and Opportunities, LILP, Cambridge, Massachusetts;

Crowe, Christopher Giovanni Dell'Ariccia, Deniz Igan, Pau Rabanal, How to Deal with Real Estate Booms: Lessons from Country Experiences, IMF "Working Paper", No 4/2011;

Dolata, Stanisław. 1999. Podstawy wiedzy o podatkach i polskim systemie podatkowym, Uniwersytet Opolski, Opole;

Dye, Richard F., Richard W. England. 2010. Assessing the theory and practice of land value taxation, Policy Focus Report of for the Lincoln Institute of Land Policy;

December 2007; Anne Paugam, Ad Valorem Property Taxation and Transition Economies, ECSIN, "Working Paper" No 9/1999;

Asa Johansson, Christopher Heady, Jens Arnold, Bert Brys and Laura Vartia, Tax and Economic Growth, OECD Economics “Department Working Papers”, No. 620, OECD Publishing, 2008. 
Etel, Leonard, Grzegorz Liszewski. 2002. Podatki majątkowe w Polsce - wybrane problemy, Kancelaria Sejmu, Biuro Studiów i Ekspertyz, Report No 202, Warszawa;

Europejskie systemy opodatkowania nieruchomości, edited by Leonard Etel, Biuro Studiów i Ekspertyz, Kancelaria Sejmu, Warszawa 2003;

European Union. (2011) Taxation Trends in the European Union: Data for the EU Member States, Iceland and Norway, <http://ec.europa.eu/taxation_customs/ taxation/gen_info/economic_

analysis/tax_structures/index_en.htm> (accessed 17 December 2011);

Felis, Paweł. 2012. Elementy teorii i praktyki podatków majątkowych. Poszukiwanie ładu w opodatkowaniu nieruchomości w Polsce z perspektywy przedsiębiorców oraz jednostek samorządu terytorialnego. Szkoła Głowna Handlowa w Warszawie, Warszawa;

Gajl, Natalia. 1996. Modele podatkowe. Podatki majątkowe, Wydawnictwo Sejmowe, Warszawa;

Grapperhaus, Ferd H.M. 2010. Podatki przez wieki. Historia wizualna, TNOiK, Toruń;

Grądalski, Feliks. 2004. Wstęp do teorii opodatkowania, SGH, Warszawa;

Grover, Richard, Ion Anghel, Virgil Pamfil. 2007. Developing quality training approaches for effective property tax administration, ERES-ESSEC Education Seminar, Paris;

Gomułowicz, Andrzej, Jerzy Małecki. 2004. Podatki i prawo podatkowe, LexisNexis, Warszawa;

Innovative Land and Property Taxation, (ed.) Remy Sietchiping, United Nations Human Settlements Programme (UN-HABITAT), Nairobi.

Johansson, Asa, Christopher Heady, Jens Arnold, Bert Brys and Laura Vartia. 2008. Tax and Economic Growth, OECD Economics "Department Working Papers", No. 620, OECD Publishing;

Krajewska, Anna. 2004. Podatki. Unia Europejska, Polska, Kraje Nadbałtyckie, PWE, Warszawa;

Mastalski, Ryszard. 2000. Prawo podatkowe, C.H. Beck, Warszawa; Property Tax Regimes in Europe, The Global Urban Economic Dialogue Series, United Nations Human Settlements Programme, Nairobi 2013.

Paugam, Anne, Ad Valorem Property Taxation and Transition Economies, ECSIN, "Working Paper" No 9/1999.

Rudnick, Rebecca, Richard Gordon, Taxation of Wealth, Victor Thuronyi (ed.), Tax Law Design and Drafting, Washington, 1996, International Monetary Fund. http://www.imf.org/external/pubs/nft/1998/tlaw/ eng/ch10.pdf; 
Slack, Enid. The Property Tax - in theory and Practice. Institute on Municipal Finance and Governance, Munk School of Global Affairs, University of Toronto, "IMFG Municipal Finance and Governance" No 2/2011;

Szczodrowski, Grzegorz. 2007. Polski system podatkowy, PWN, Warszawa;

The Act of 15th November 1984 on Agriculture Tax (Journal of Laws 1984 No 52 item 268, as amended);

The Act of $30^{\text {th }}$ October 2002 on Forest Tax (Journal of Laws 2002 No 200 item 1682 , as amended);

The Act of $12^{\text {th }}$ January 1991 on Local Taxes and Fees (Journal of Laws 1991, No 9 item 31, as amended). 